\title{
Towards a sustainable local business community by women's empowerment programs through corporate social responsibility (CSR)
}

\author{
Lutfia Nurul Hidayati ${ }^{1, *}$, Ary Miftakhul Huda ${ }^{1}$, and Merintha Suryapuspita ${ }^{1}$ \\ ${ }^{1}$ Master Student of Public Policy Department, Faculty of Social and Political Science, Airlangga \\ University, Indonesia
}

\begin{abstract}
Based on data from Central Bureau of Statistics, the population of Indonesia in 2016 amounted to 258.71 million people, consisting of 128.72 million women and 129.99 million men. Thus, women need to be empowered to increase their competence so that they can contribute in the national economy. The aim of this paper is to analyze the impact of women's empowerment into a sustainable local business community through Corporate Social Responsibility (CSR). The qualitative research methodology was conducted in this study. Data collection is conducted through in-depth interview with the related women. The informants in this study were the women who were involved in CSR program located in Kampung Kue, Surabaya City. This research uses the theory of women empowerment by Nursahbani Katjasungkana in discussion of Strategic Plan Team of National Development. The results show that women empowerment programs have a positive impact on women's selfdevelopment in Kampung Kue. Women become skilled and have the ability to become independent entrepreneurs. Thus, women have additional income and are able to increase household incomes. In addition, the slum neighborhoods in Kampung Kue previously became a productive local business community due to the empowerment program.
\end{abstract}

\section{Introduction}

The global market is an activity that aims to advance a country. In addition to advancing the global market country also aims to prosper the community more evenly. Countries that are members of the global market must face competition from one another. European countries respond to the global market by developing and improving small and medium business groups. The policy was taken with the aim of accelerating the improvement of the welfare of the people in Europe evenly. This policy is a view for other countries because small and medium enterprises are more reliable and can be used as a symbol of a country, one of which is Indonesia. Small and Medium Enterprises in Indonesia can be called a gold

\footnotetext{
* Corresponding author: lutfifilut@gmail.com
} 
business. This was evidenced during the monetary crisis, at that time those who were able to survive and continue to grow were the small and medium enterprises. In addition, according to Sudaryanto et al (2014) this field can absorb a large workforce and can provide opportunities for SMEs to grow and compete with companies (solid capital). However, in the implementation of the small and medium business it has not fully involved women in the implementation.

Based on data from the 2016 National Socio-Economic Survey (Susenas) and Indonesian Population Projection conducted by the Central Statistics Agency (BPS), Indonesia's population in 2016 totaled 258.71 million people, consisting of 128.72 million women and 129.99 million man. From these data can be seen the number of women more than men. From the results of data processing of the Central Statistics Agency, namely the 2004 National Socio-Economic Survey. In urban areas 63.3\% of mothers aged less than 40 years who have children, only take care of the household. Whereas in rural areas, mothers who take care of the household alone are around 52.7\%. If added, the number of women who only take care of their household is $116 \%$. With this figure it can be interpreted that women's participation is still very minimal in the economic sector. This should be utilized by the Small and Medium Enterprises sector to empower women more in the implementation of their production. With the Corporate Social Responsibility, it is expected that the role of women in the Small and Medium Enterprises sector can be more in the movement so that the quality of women's resources in Indonesia can increase and economic growth can increase as well.

Especially now that companies are required to carry out their responsibilities in various fields. This should be utilized by the Micro, Small and Medium Enterprises sector to empower women more in the implementation of their production. With the Corporate Social Responsibility, it is expected that the role of women in the medium-sized micro business sector can be more in the movement so that the quality of women's resources in Indonesia can and economic growth can increase as well.

\section{Woman empowerment in global and Indonesia}

The research of women empowerement has been conducted all around the world. Adjei (2015) [1] conducted a critical research in Africa about "Gender Empowerment Measure" developed to gender inequality. The results showed that it should be more considered about context and values. After that, Mishra (2015) [2] analyzed about the cycles of menstrual between "rural women" and "adolescent girls". Then, The high awareness in the hygiene of menstrual are coming from the girls who are from "towns" and "metro cities". Then, Hopkinson and Aman (2017) [3] had a research in India, Naveed and Suhaib (2018) [4] in Pakistan. Then, Evans, Mayo, and Quijada (2018) [5] in America.

Women's empowerment can also be optimized through collaboration with companies through CSR programs. The concept of CSR for empowering women has already conducted around the world. Abdullah, Johari, and Bakri [6] (2015) studied about innovative collaborations for university students and women entrepreneurs in Malaysia. After that, Banks (2016) [7] reviewed the contribution of The Coca-Cola Company to national stability using The Golden Triangle Model. Besides, Celis et al. (2017) [8] conducted an in Spain, Kapoor (2017) [9] in India, and Gaither, Austin, and Schulz (2018) [10] in Coca-Cola Company.

Then, the policies related to Corporate Social Responsibility (CSR) have been regulated by the Government of Indonesia. CSR is very important because of the increasing number of industrial companies in Indonesia. Thus, it is expected to have a positive impact on the community and the environment. Regarding Indonesia Law (Number 47 in 2007) about "Limited Liability Companies", CSR concept contained in it also covers the environment. 
In addition, there is Law Number 25 Year 2007 concerning Investment. The Investment Law also includes an article governing CSR.

\section{Research methodology}

The research method used is descriptive research method with case study design. This study used a qualitative approach through interviews with SME that established partnership relationships corporate social responsibility. In analyzing the Women's Empowerment Programs through Corporate Social Responsibility (CSR) use theory by Nugroho (2008) [11].

\section{Discussion}

In the global era, the role of women contributes to improving and strengthening the economic sector. This can be seen from one of the Small and Medium Enterprises (after that called SME) in Surabaya which experienced rapid progress in the economy, namely SME Kampung Rungkut Lor, Surabaya City. The SME was established initiated by the economic hero named Mrs. Choirul Mahpudiah. Initially these SMEs were formed because the economy in the Village was very low seen from the large number of families who still received assistance from the government, mothers who did not have income and only became housewives. According to Riant Nugroho (2008: 164), the objectives of the women's empowerment program are: 1) increasing the ability of women to involve themselves in development programs, as active participation (subject) so as not only to become objects of development as they have been, 2) improve the ability of women in leadership, to increase bargaining positions and involvement in every development both as planners, implementers, as well as monitoring and evaluating activities, 3 ) improving the ability of women to manage household-scale businesses, small industries and large industries to support an increase in household needs, as well as to open productive and independent employment opportunities; 4) improve the role and function of women's organizations at the local level as a means of empowering women to be actively involved in development programs in their areas of residence.

Through the development of human resources training has been held, both the training held by the SME Kampung Kue and training held from CSR with PT. Indofood Sukses Makmur Tbk, as well as support from the Cooperative Service and the Industry and Trade Office. This is aimed at improving the skills and abilities of the members of the SME Kampung Kue Rungkut Lor and the Kampung Kue community through training that provides a briefing for its members to be able to improve the welfare of their families and be able to live properly and fulfill their daily lives.

There is a significant increase in income after being empowered by the CSR of PT. Indofood Sukses Makmur Tbk, can be seen from Fig. 2. 


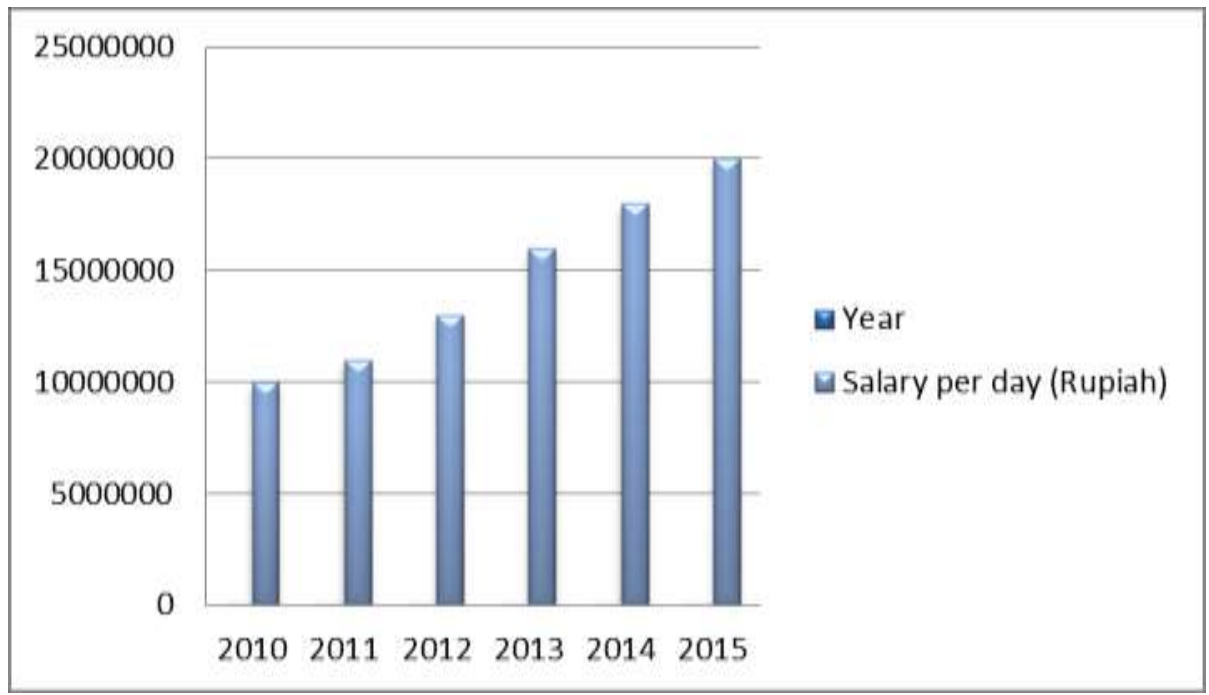

Fig. 1. SME salary after having CSR program.

In this training there were training in making cakes and simple bookkeeping training. For training in baking, for example, how to make cakes with various variants ranging from pastries to wet cakes, while simple bookkeeping training is to make financial statements of Small and Medium Enterprises so that the emergence of accountability and transparency in SME development management. More training as a means aimed at efforts to further activate the work of previously less active members of the organization, reduce negative impacts due to lack of education, limited experience, or lack of confidence from certain members or groups of members. One manifestation of the development of the first productive business is to collaborate with PT. Indofood Sukses Makmur Tbk, both from giving training in making cakes and providing public facilities such as street headbands, aprons, Bogasari tables to trade cakes. The provision of these facilities is expected to support SME members in trading. In addition to collaborating with Bogasari, there is also support from the cooperative and industrial and trade services. Assistance provided by cooperatives in the form of simple bookkeeping training and the provision of Home Industry Licensing by the cooperative service and industry and trade services.

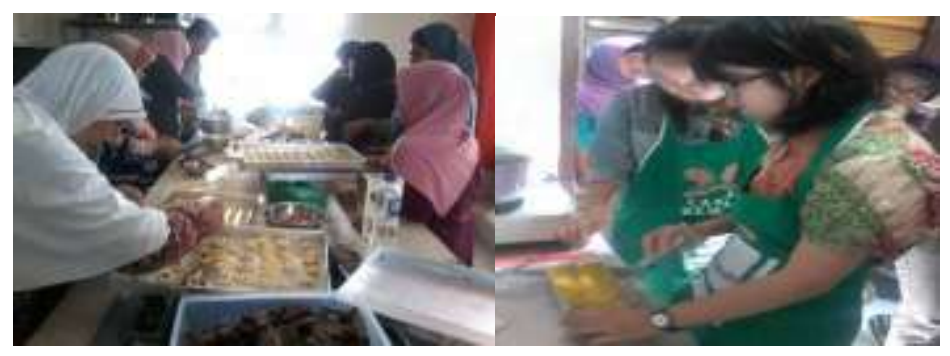

Fig. 2. Cake making training for SME.

From the 65 members of the SME, Kampung Kue, there are 11 members who already have a PIRT business license and the rest are still in the process of making. The development of SMEs themselves in marketing began at 3:30 a.m., whose sales efforts entrusted their cakes to the market, so that in the end they opened their own stalls in front of their homes. From there there began to be middlemen who came to the cake village. So that 
there was coverage from the TV station which covered the activities of SME Kampung Kue activities. From there, there are many people who understand the existence of Kue Kampung. One of the members who has successfully entered the hero market is the product of Mrs. Choirul Mahpudiah with the name of cake cake product. To enter the hero market also through several stages, starting from checking worthy goods or not after that, providing technical training on how to access the market to enter the Hero Supermarket.

SME development is also supported by web management and information, notifications, news or news with sources of information seeking and using information to find out the development of Kampung Kue SMEs. Information development can be measured through the level of technology utilization. There is a provision of information on the SME Kampung Kue website that has not been used properly, because the SME Kampung Kue officials are busy with their respective businesses so that they have not been optimally implemented with the website. Providing assistance from the Surabaya City Government in collaboration with PT Telkom Indonesia to go to the Digital SME village with 2 computers and desks and 5 chairs which later can complete the facilities and support the development of SME Kampung Kue. Not only is it equipped with wifi and indiehome. PT Telekomunikasi Indonesia Tbk also opened loan funding assistance amounting to IDR 20,000,000 / per person who is indeed a member of SME.

Training had given a positive impact on SME members, especially in baking, so members have more expertise. Members who have successfully entered the supermarket are products from Mrs. Choirul Mahpudiah with the name Pawon Kue. SME development is carried out in collaboration with PT. Indofood Sukses Makmur Tbk and support from cooperatives and industry and trade services. Collaboration with PT. Indofood Sukses Makmur Tbk through providing training in baking and facilities in business support. Support from the Office of Cooperatives and the Office of Industry and Trade in the form of giving permission to a Home Industry Company. assistance from the Surabaya City Government in collaboration with PT Telkom Indonesia to go to the Digital SME village with 2 computers, tables and 5 chairs which later can complete the facilities to support the development of SME Kampung Kue. Not only is it equipped with wifi and indiehome. PT Telekomunikasi Indonesia Tbk also opened loan funding assistance amounting to IDR $20,000,000 /$ per person who is indeed a member of SME.

\section{Conclusion}

Based on the discussion, training has given positive impacts on SME members, especially in baking, so members have more expertise. Members who have successfully entered the supermarket are products from Mrs. Choirul Mahpudiah with the name Pawon Kue. SME development is carried out in collaboration with PT. Indofood Sukses Makmur Tbk and support from cooperatives and industry and trade services. Collaboration with PT. Indofood Sukses Makmur Tbk through providing training in baking and facilities in business support. Support from the Office of Cooperatives and the Office of Industry and Trade in the form of giving permission to a Home Industry Company. assistance from the Surabaya City Government in collaboration with PT Telkom Indonesia to go to the Digital SME village with 2 computers, tables and 5 chairs which later can complete the facilities to support the development of Kampung Kue. Not only is it equipped with wifi and indiehome. PT. Telkom also opened loan funding assistance amounting to IDR 20,000,000 / per person who is indeed a member of SME. 


\section{References}

1. S.B. Adjei, Psychol. Dev. Soc. J. 27, 58-80 (2015)

2. S. Mishra, J. H. Manag. 17, 395-406 (2015)

3. G. Hopkinson, A. Aman, Mark. Theor 17, 305-321 (2017).

4. M.A. Naveed, \& A. Suhaib, Inf. Dev.

5. C.A. Evans, L.M. Mayo, M. A. Quijada, Nonprofit Volunt. Sect. Q. (2018).

6. J. Abdullah, H.S.Y. Johari, A.A. Bakri, W.M.W.A Razak, Procedia Soc. Behav. Sci. 168, 97-103 (2015)

7. H. Banks, Bus. Horiz. 59, 455-461 (2016)

8. I.L.R. de Celis, S.F. de B. Güémez, M. del M.A. Almeida, E. V. Balmaseda, Saf. Sci. 91, 61-70 (2017)

9. G.K. Kapoor \& S. Dhamija, Emerg. Econ. Stud. 3, 98-112 (2017)

10. B.M. Gaither, L. Austin, M.C. Schulz, PR Inq. 7, 45-61 (2018)

11. R. Nugroho, Women empower (Andi Offset Publisher, Jakarta, 2008)

12. R. Sudaryanto \& R.R. Wijayanti, The str. of empower MSMEs to face the ASEAN free mkt. (2014) 